\title{
УЛИЧНАЯ ПРЕСТУПНОСТЬ: СОСТОЯНИЕ, ПРИЧИНЫ И ПРОГНОЗ РАЗВИТИЯ
}

\author{
Голубых Н.В.
}

Аннотация: В данной статье приведен анализ современного состояния и динамики уличной преступности, наибольшая опасность которой заключается, прежде всего, в многообразии ее форм и методов воздействия одновременно на большие массы людей. Автор статьи также уделяет значительное внимание криминогенной детерминации исследуемого преступного явления. На основании проведенного исследования предложень два варианта прогноза развития криминальной ситуации, приведен прогноз развития и распространения уличной преступности на среднесрочную перспективу, а также меры направленные на предупреждение уличной преступности. Метод или методология исследования: Для достижения цуели и решения задач, стоящих перед исследованием были применень общенаучные и частно-научные методы, а именно: анализа, синтеза, структурно-логический метод, статистический, метод сравнительно-правового анализа метод от конкретного к абстрактному и иные методы научного познания. Научная новизна и выводы: На основании проведенного исследования современного состояния и основных тенденций распространения и развития уличной преступности, посредством использованных методов в статье предложены меры общесоциального и специильнокриминологического характера, которые могут лечь в основу успешного противодействия анализируемого противоправного деяния.

Ключевые слова: Улица, преступность, система, Динамика, Информация, прогноз, структура, преступление, Виктимологическая профилактика, материальная окружающая среда.

Понятие уличной преступности неразрывно связано со специфическими особенностями пространства, где совершаются преступления данного типа, и возникающими здесь криминальными ситуациями. Улицы, наряду с площадями, проездами, набережными, скверами и бульварами, относятся к территории общего пользования, пространству, которым беспрепятственно пользуется неограниченный круг лиц, и одновременно - к местам постоянного пользования. Как правило, уличная преступность совершается лицами и в отношении лиц, не связанных между собой укладом повседневной жизни.
Таким образом, под уличной преступностью понимается система преступлений, проявляющаяся на открытой для доступа части инфраструктурной территории населенного пункта (характеризующейся неравномерностью социального контроля, преобладающей анонимностью поведения) и требующая специфических государственных антикриминогенных мер воздействия. Уличная преступность как системное явление имеет ряд закономерностей возникновения, развития, функционирования, зависящих от характеристик городов, общего уровня их развития, социально-демографических особенностей 
населения, как социальное явление во многом связана с элементом случайности.

Состояние анализируемого вида преступности в Российской Федерации определяется общим количеством зарегистрированных преступлений, а также числом лиц, их совершивших, на конкретной территории за календарный год. Так, в 2013 г. было зарегистрировано на улицах, площадях, в парках и скверах 463685 (-0,5\%) преступлений, в том числе: $204570(-2,7 \%)$ краж, $51853(-15,7 \%)$ грабежа, $6563(-13,6 \%)$ разбойных нападения. Удельный вес уличной преступности на территории Российской Федерации за 2013 год составил 21,01\%. Всего за период с 2010 по 2013 год было зарегистрировано 1740037 преступлений, совершенных на улицах, площадях, в парках и скверах.

Динамика исследуемой преступности за последние шесть лет, в целом, характеризуется ростом, но в отдельные периоды, в том числе и в 2013 году, - незначительным спадом: так, в 2010 г. было зарегистрировано - 397870 преступлений, в 2011 г. $-412406(+3,7 \%)$, в 2012 г. $-466076(+13$ \%), в 2013 - 463685 (-0,5\%). Рост зарегистрированных преступлений на улицах, площадях, в парках и скверах с 2010 г. по 2013 г. составил 65815 преступлений (т.е. произошло увеличение уличной преступности в 1,2 раза).

(январь-май 2014 г. +5,7\%)

В Свердловской области количество зарегистрированных преступлений анализируемой категории составило в 2013 году 16345, что представляет 23,6\% от общего числа преступлений, зарегистрированных на территории региона (69231). В 2013 году в регионе совершено 3940 тяжких и особо тяжких преступлений на улицах, площадях, в парках и скверах, что составляет $24,1 \%$ от общего числа преступлений анализируемой категории. Наиболее часто на улицах совершаются кражи - 7221 преступление, что составляет 44,1\% в общей структуре. Следующим по распространенности уличным преступлением является грабеж - 2041 (12,4\%). На третьем месте находится неправомерное завладение автомобилем или иным транспортным средством без цели хищения - 1055 преступлений $(6,4 \%)$.

В 2010 году на территории Свердловской области было выявлено 18051 преступление рассматриваемой категории, что составило $18,7 \%$ в общей структуре преступности (96422 преступления). Удельный вес тяжких и особо тяжких преступлений в 2010 году составил 28,2\% (5103 преступления). Кражи (5847) и грабежи (3847) заняли лидирующие позиции в 2010 году в структуре уличной преступности, третьим по численности было причинение тяжкого вреда здоровью (3491).

В 2011 году на территории Свердловской области было выявлено 13127 преступлений анализируемой группы, что составило 16,9\% в общей структуре преступности (77347 преступлений). Удельный вес тяжких и особо тяжких преступлений в 2011 году составил 28,6\% (3765 преступлений). Кражи (4654) и грабежи (2217) заняли лидирующие позиции и в 2011 году, на третье место переместились угоны (917).

В 2012 году на территории Свердловской области на улицах, площадях, в парках и скверах было выявлено 13793 преступления рассматриваемой категории, что составило 19,2\% в общей структуре преступности (71549 преступлений). Удельный вес тяжких и особо тяжких преступлений в 2012 году составил 24,5\% (3393 преступления). Самыми распространенными стали кражи (5525), грабежи (2153) и угоны (973).

Таким образом, характеризуя динамику уличной преступности на территории Свердловской области за истекшие четыре года, можно отметить снижение количества преступлений анализируемой категории в 2011 году на 4924 преступления (-27,2\%), небольшой рост в 2012 году на 666 преступлений (+5\%), и достаточно существенное увеличение в 2013 году на 2552 преступления $(+18,5 \%)$. Всего за четыре года уличная преступность на территории региона снизилась на 1706 преступлений (-9,4\%). Можно отметить увеличение за истекший период удельного веса уличной преступности в общей структуре преступности в Свердловской области $(+4,9 \%)$. На 1163 преступления уменьшилось за четыре года количество тяжких и особо тяжких преступлений, совершенных на улицах $(-22,7 \%)$. Кроме того, можно отметить снижение удельного веса тяжких и особо тяжких преступлений в общей структуре уличной преступности на 4,1\%. Кражи и грабежи являются наиболее часто совершаемыми на улице преступлениями в течение всех четырех лет, однако если по грабежам наблюдается снижение количества зарегистрированных преступлений $(-46,9 \%)$, то по кражам - рост $(+23,4 \%)$. Существенное снижение за четыре года наблюдается по причинению тяжкого вреда здоровью (-90,1\%). Примерно на одном уровне находится количество угонов, которые в последние три года занимают третье место в общей структуре уличной преступности региона. 
Информация о состоянии уличной преступности на территории Свердловской области за период с 2010 по 2013 гг.

\begin{tabular}{|c|c|c|c|c|}
\hline & 2010 & 2011 & 2012 & 2013 \\
\hline $\begin{array}{l}\text { Количество } \\
\text { преступлений, } \\
\text { зарегистрированных } \\
\text { в общественных местах }\end{array}$ & 20825 & 15686 & 19072 & 22783 \\
\hline $\begin{array}{l}\text { Количество } \\
\text { преступлений, } \\
\text { зарегистрированных на } \\
\text { улице }\end{array}$ & 18051 & 13127 & 13793 & 16345 \\
\hline \multicolumn{5}{|l|}{ Из них: } \\
\hline $\begin{array}{l}\text { - тяжких и особо тяжких } \\
\text { преступлений }\end{array}$ & 5103 & 3765 & 3393 & 3940 \\
\hline - убийств & 66 & 69 & 50 & 69 \\
\hline $\begin{array}{l}\text { - причинения тяжкого } \\
\text { вреда здоровью }\end{array}$ & 3491 & 304 & 320 & 343 \\
\hline - грабежей & 3847 & 2217 & 2153 & 2041 \\
\hline - разбойных нападений & 300 & 233 & 287 & 306 \\
\hline - хулиганств & 112 & 60 & 81 & 104 \\
\hline - краж & 5847 & 4654 & 5525 & 7221 \\
\hline - угонов & 1056 & 917 & 973 & 1055 \\
\hline
\end{tabular}

На состояние уличной преступности оказывает негативное влияние ряд региональных факторов экономического, социального, политического, демографического и географического характера:

- международный финансовый кризис и безработица;

- резкое расслоение населения по имущественному признаку;

- слабая социальная защищенность граждан, низкий уровень жизни отдельных категорий граждан, проживающих в Свердловской области, и, как следствие, высокий уровень социальной напряженности;

- неравномерная плотность населения на территории Свердловской области и концентрация основной части населения в крупных индустриальных центрах;

- нерегулируемое перемещение сельского населения в города из-за распада агропромышленного комплекса;
- низкий антикриминогенный гражданский потенциал, заключающийся не просто в снижении доверия к правоохранительным органам, но и в ослаблении толерантного отношения граждан к правоохранительной деятельности и ее результатам;

- сохранение значительного числа негативных фоновых явлений, в частности проституции, бродяжничества, игромании, наркотизма и алкоголизма;

- низкий уровень образования лиц, совершающих преступления; слабая организация досуга несовершеннолетних, недостаточное количество спортивных секций (в силу климатических условий отсутствует возможность занятий видами спорта на открытой местности), слабая пропаганда здорового образа жизни и низкая доступность бесплатного образования;

- высокая концентрация исправительных учреждений, а соответственно, и лиц, ранее судимых, то есть контингента, традиционно 
используемого в освоении территорий и природных ресурсов региона и находящегося в сложных условиях постпенитенциарной адаптации;

- наличие в ряде районов региона благоприятных условий для рынков сбыта наркотиков и удобного транзита для наркокурьеров;

- интенсивная миграция и активное освоение территории гражданами ближнего и дальнего зарубежья;

- высокая мобильность и плотность населения мегаполисов; обезличенность и анонимность поведения на улицах городов; архитектура, планировка городских кварталов; недостаток социального контроля уличного пространства; несовершенство в организации работы отдельных социальных предприятий и учреждений;

- недостаточная освещенность улиц, информационность уличных указателей; небольшое количество камер видеонаблюдения в местах массового пребывания людей.

В связи с вышеизложенным можно предложить два варианта прогноза развития криминальной ситуации на улице на среднесрочную перспективу.

Один из них оптимистический, предполагающий снижение степени влияния негативных факторов на ситуацию на улицах, площадях, в парках и скверах.

В соответствии с данным сценарием развития ситуации не следует ожидать существенного роста уличной преступности в Свердловской области, ее значительное увеличение в 2013 году не нужно рассматривать как тенденцию, а, скорее, следует считать результатом изменения методики подсчета ее показателей. Соответственно, в ближайшие пять лет будет наблюдаться постепенное снижение показателей уличной преступности, как и понижение ее доли в общей преступности региона.

Скорее всего, продолжит свое развитие и наметившаяся тенденция по изменению в лучшую сторону характера уличной преступности в регионе. Продолжит сокращаться удельный вес тяжких и особо тяжких преступлений, примерно на $0,5-1,5 \%$ ежегодно, что к 2018 году должно привести к показателю около $19 \%$.

Вполне вероятно сокращение показателей основных преступлений, образующих структуру уличной преступности. Так, продолжится снижение количества уличных грабежей на 5\% ежегодно, что приведет к 2018 году к показателю примерно в 1580 преступлений. Возможны незначительные колебания показателей убийств, при- чинения вреда здоровью, разбойных нападений, хулиганства, угонов. Скорее всего, не удастся переломить ситуацию увеличения числа совершаемых на улицах краж чужого имущества, что к 2018 году, возможно, приведет к показателю в 9000 таких преступлений.

Структура уличной преступности в Свердловской области в ближайшие пять лет вряд ли изменится, по-прежнему будут преобладать имущественные преступления, прежде всего кражи.

Второй вариант прогноза - пессимистический, предполагающий усиление степени влияния ранее перечисленных негативных факторов экономического, социального, демографического, политического характера.

В этом случае продолжится рост уличной преступности. При этом если учитывать динамику последнего периода, возможно возрастание показателей на 18-19\% ежегодно, что к 2018 году приведет к показателю, превышающему 38000 преступлений. Возрастет и доля преступлений, совершаемых на улицах, в общей структуре преступности Свердловской области. Замедлится снижение удельного веса тяжких и особо тяжких преступлений в общей структуре уличной преступности. Наметится прирост преступлений данных категорий, причем если учитывать годовой прирост в 2013 году - на 16\% ежегодно.

Если сравнивать только показатели 2013 и 2012 годов, то можно обнаружить рост показателей почти всех основных преступлений, образующих уличную преступность. Если рассматривать данный факт как наметившуюся тенденцию, то к 2018 году можно спрогнозировать увеличение количества совершаемых на улицах убийств до 342 преступлений (+38\% ежегодно), причинения тяжкого вреда здоровью - до 479 преступлений (+7\% ежегодно), разбоев - до 407 преступлений (+6\% ежегодно), хулиганства - до 354 преступлений (+28\% ежегодно), краж - до 26808 преступлений (+30\% ежегодно), угонов - до 1548 преступлений (+8\% ежегодно).

Для исключения развития ситуации по подобному сценарию необходимо предпринять ряд мер, направленных на предупреждение роста уличной преступности:

1. Введение и совершенствование работы аппаратно-программных комплексов «Безопасный город».

(установлено по области 985 камер уличного видеонаблюдения, объединенных в 36 систем 
наблюдения, с выводом информации на сервера диспетчерских центров дежурных частей территориальных органов МВД России по муниципальным образованиям СО.

Функционируют 5176 кнопок тревожной сигнализации с выводом сигнала на пункт централизованной охраны отделов вневедомственной охраны, установленные в местах с массовым пребыванием граждан.

Населением используется 82 (на уровне 2013 г.) аппарата экстренной связи «гражданин-полиция» для незамедлительного сообщения в ОВД о совершаемых (совершенных) правонарушениях, из них 23 (на уровне 2013 г.) функционируют на объектах Екатеринбургского метрополитена.

С помощью АПК «Безопасный город» зафиксировано 2117 административных правонарушений, раскрыто 415 преступлений).

Увеличение количества нарядов патрульно-постовой службы полиции на территории обслуживания и оптимизация маршрутов патрулирования в зависимости от времени суток, дня недели, конкретных дат и т.д.

2. Оснащение подразделений патрульно-постовой службы полиции современными средствами связи и коммуникации, специальными средствами, транспортом.

3. Оборудование всех улиц освещением, а также продление времени его работы ночью.
4. Установка систем видеонаблюдения и сокращение времени работы увеселительных заведений.

5. Оснащение технических объектов средствами связи с полицией;

6. Активное привлечение населения к патрулированию улиц посредством возвращения народных дружин в соответствии с Федеральным законом Российской Федерации от 2 апреля 2013 года № 44-Ф3 «Об участии граждан в охране общественного порядка».

7. Виктимологическая профилактика и работа с населением в отношении того, как не стать жертвой уличного преступления, в том числе в школах, детских досуговых учреждениях и пр.

8. Осуществление работы по социальной адаптации лиц, отбывших наказание за преступления, совершенные на улицах.

9. Совершенствование методов превентивной работы с лицами, склонными к совершению преступлений на улицах, а равно по выявлению таких лиц.

Таким образом, комплексное воздействие на материальную окружающую среду вкупе с виктимологической профилактикой позволит не только значительно сократить число уличных преступлений, но и повысить эффективность работы органов внутренних дел по их предупреждению.

\section{Библиография:}

1. Виктимологический аспект уличной преступности // Право, политика, экономика: проблемы развития и взаимосвязи: Сб. трудов докторантов, адъюнктов и соискателей. Вып. 19 / Под общ. ред. В.П. Сальникова. СПб.: Санкт-Петербургский университет МВД России, 2004.

2. Детерминанты уличной преступности // Современное общество и правоохранительные органы: проблемы теории и практики: Сб. трудов докторантов, адъюнктов и соискателей. Вып. 18. Часть 2 / Под общ. ред. В.П Сальникова. СПб.: Санкт-Петербургский университет МВД России, 2003.

3. Клейменов М.П. Криминология: учебник. Изд. 2-е, испр. и доп. М.:Норма, 2012.

\section{References (transliterated):}

1. Viktimologicheskii aspekt ulichnoi prestupnosti // Pravo, politika, ekonomika: problemy razvitiya i vzaimosvyazi: Sb. trudov doktorantov, ad"yunktov i soiskatelei. Vyp. 19 / Pod obshch. red. V.P. Sal'nikova. SPb.: Sankt-Peterburgskii universitet MVD Rossii, 2004.

2. Determinanty ulichnoi prestupnosti // Sovremennoe obshchestvo i pravookhranitel'nye organy: problemy teorii i praktiki: Sb. trudov doktorantov, ad"yunktov i soiskatelei. Vyp. 18. Chast' 2 / Pod obshch. red. V.P Sal'nikova. SPb.: Sankt-Peterburgskii universitet MVD Rossii, 2003.

3. Kleimenov M.P. Kriminologiya: uchebnik. Izd. 2-e, ispr. i dop. M.:Norma, 2012. 